\title{
The Impact of Islamic Banks Growth on Conventional Banks Development: A Comparative Study Between United Arab Bank (UAB) and Sharjah Islamic Bank (SIB)
}

\author{
Muhamad Abdul Aziz Muhamad Saleh Jumaa \\ City University College of Ajman (CUCA), Ajman, UAE
}

\begin{abstract}
The fact that the global crisis did not affect Islamic banks impressed all financial institutions and providers around the world; the fast growth and expansion in less than one century since it was first established in 1963 in Egypt. Many studies and researches discussed in theoretically the used principles and instruments in Islamic banks to achieve financial stability under any financial situation. However, this study will test the growth of Islamic banks and conventional banks after the crisis in both categories (asset and profitability) between United Arab Bank (UAB) ${ }^{1}$ and Sharjah Islamic bank $(\mathrm{SIB})^{2}$. In addition, the study found that Islamic banking system is more efficient and stable against any hard, sudden financial situation, and is less risky even though the growth is more likely steady. Also, it found that conventional banks are more profitable but less financially stable and more risky.
\end{abstract}

Keywords: Islamic banks, conventional banks, accounting, finance, financial statements

\section{Introduction}

The huge expansion of Islamic banks around the world in Muslim and Non-Muslim countries attracted the attention of every financial institution, only by looking at the young age of Islamic banks in the financial market. In addition, the fact that Islamic banks were less or not affected by the 2007-2008 financial crisis attracted many Non-Muslim customers in foreign countries. Many researchers made studies, books, and theories about Islamic banks revealing the differences of the principles, financial instruments, and system, which are different from Islamic banks to conventional banks.

Both Islamic banks and conventional banks in general give the same financial services to customers and business, but the ways or instruments that the financial services are functioned in the both banks are different.

This research will discuss some differences between Islamic banks and conventional banks in the form of case study between one Islamic bank (Sharjah Islamic Bank) and one conventional bank (United Arab Bank) in UAE. It did a comparison between them, the growth of each bank in both profit and asset.

\footnotetext{
Muhamad Abdul Aziz Muhamad Saleh Jumaa, Ph.D., assistant professor, Department Chair, Department of Finance \& Accounting, City University College of Ajman (CUCA), Ajman, UAE.

Correspondence concerning this article should be addressed to Muhamad Abdul Aziz Muhamad Saleh Jumaa, Department of Finance \& Accounting, City University College of Ajman (CUCA), 18484 Ajman, UAE.

${ }_{1}^{1}$ http://www.uab.ae/cms/.

2 http://www.sib.ae/home.
} 


\section{Research Objectives}

The main objective of this study is to measure the effect of Islamic banks' growth on the growth of conventional banks in both the asset and profit categories.

\section{The Hypothesis}

- The growth of Islamic banks is faster than conventional banks.

- The net income for the Islamic banks is more than conventional banks.

- Islamic banks use profit rate, while conventional banks use interest rate.

\section{Research Questions}

Does the growth of Islamic banks affect the growth of conventional banks?

\section{Literature Review}

Muhammad Hanif (2011) compared Islamic banking and conventional banking and differentiated between them: that Islamic banks are not using the same system in any conventional bank under the cover of Islamic bank name. The evidences showed that Islamic banks used the Shari'ah principles in a very efficient and effective way to achieve financial stability.

Zehri, Abdelbaki, and Bouabdellah (2012) published a study in 2012 by applying financial ratios to compare the impact of financial crisis on Islamic banks and conventional banks during the crisis period and the pre-crisis period. This study result found that Islamic banks were more stable than conventional banks during the crisis 2007-2008, the main reason for this result was that Islamic banks were depending on the Shari'ah ruling.

Mobeen Alam, Noreen, Karamat, and Ilyas (2011) studied the performance of Islamic banks after the financial crisis and found that Islamic banks system remained progressing with growth $8.85 \%$, and value of asset reached 895 USD billion in 2010. Moreover, it highlighted the reliability of Islamic banks as a free-interest financial institution that depends on Shari'ah ruling unlike conventional banks.

Miniaoui and Gohou (2013), this study examined the performance between productivity and profitability of the main financial instruments of the Islamic banks after the crisis on national banks in UAE. The results showed that conventional banks system was performing better than Islamic one before the global crisis but everything changed after the crisis, the performing gap between them changed, Islamic banks achieved better performance than conventional banks after the financial crisis.

\section{Research Design}

This study is reporting and monitoring study contained both quantitative and qualitative studies. It has been mentioned in the beginning that the main purpose from this research is testing, measuring, and comparing the growth of Islamic banks and conventional banks after the crisis in both categories (asset and profitability). The time dimension is a cross-sectional study carried to give a snap-shot during the period between 2010-2011-2012-2013-2014 financial position for the both banks. In addition, the tropical scope will be a statistical, and the research environment was inside the collage (field conditions).

\section{Data Collection Design}

The secondary data were collected reports from the websites, official websites of both United Arab Bank 
and Sharjah Islamic Bank, and other Islamic financial institutions. Also the author collected data and information from published studies that were done by instructors around the world discussing and comparing the Islamic banking sector and the conventional banking sector before, during, and after the financial crisis.

\section{What Is the Definition of Islamic Banking?}

Islamic banking refers to a system of banking activity, which is consisting with the principles of Islamic rulings (Shari'ah). You can see the practical application of these principles through the development of Islamic economies, these principles clearly have emphasis on the ethical values and morality in all dealings that have a huge appeal either socially or financially.

The Islamic rulings prohibit the acceptance and payment of interest in any type of transactions either lending (loans) or acceptance (deposits) of money, goods, and services, which is known in Islam as Riba ${ }^{3}$. The Islamic banks appeared in the late 20th century in Islamic countries to provide an alternative to the Muslims, instead of the conventional banks that accept and deal with interest charges, which is against the Shari'ah in Islam, although Islamic banking services are not restricted to Muslims only.

The actual process way to obtain the actual Shari'ah is the Qur'an as well as the actual saved sayings and steps involving Prophet Muhammad (pbuh) - the actual Hadith. Wherever methods to problems are not seen in these places, rulings are manufactured based on the comprehensive agreement of the local community leaned historians, unbiased thought of an Islamic college student and custom made, providing that like rulings to never deviate through the simple theories inside Qur'an. This is one of the characteristics of the Islamic banking against the long history of conventional banks.

\section{What Is the Definition of Conventional Banking?}

Classification connected with "commercial bank" as well as "conventional bank": bank. Bank is usually a financial institution to provide solutions or services, such as accepting deposits, home loan credit, giving business loans and car loans, and basic investment products like certificates of deposit and savings accounts .

The original professional financial institution is usually a offline association together with tellers, safe and sound deposit boxes, vaults, as well as ATMs. Nevertheless, many professional finance institutions will not have almost any bodily branches as well as call for shoppers to finish almost all orders by means of telephone as well as Net (technology services). In trade, they generally spend higher interest levels on ventures as well as remains, as well as demand decreases expenses, which is often a pattern within the last three years.

\section{How Are Islamic Banks Different From Conventional Banks?}

Islamic bank has the very same goal seeing that standard bank apart from it performs relative to the guidelines associated with Shari'ah unlike standard financial institutions, which is usually referred to as Fiqh al-Muamalat (Islamic regulations with transactions) which usually described inside simple words and phrases "sharing income and also loss" and also prohibiting gathering or providing "interest, fees, expenses, and so on". However, the things Islamic bank need to do are that they should be often employed in line with this Shari'ah

\footnotetext{
${ }^{3}$ Riba: is an Arabic term mentioned in the Holy Quran, literally, "increase", "addition", or "growth". Technically, it refers to the "premium" that must be paid by the borrower to the lender along with the principal amount as a condition for the loan or an extension in its maturity. Interest as commonly under stood today, is regarded by predominant majority of "fuqaha" to be equivalent to Riba (profit).
} 
and its particular practical application with the progress associated with Islamic economics. Many of the guidelines inside Islamic bank are centered and also normally recognized around the globe, for hundreds of years rather than generations. These kinds of guidelines will not be new nevertheless debatably, Muslim scientist has modified their particular initial talk about above the generations.

This process source of the particular Shari'ah may be the Qur'an and then the particular recorded sayings as well as actions of Prophet Muhammad (pbuh) - the particular Hadith. Wherever solutions to problems are not within the two of these solutions, rulings are created using the comprehensive agreement of your neighborhood leaned students, impartial reasons of the Islamic college student as well as custom, provided that these kinds of rulings never deviate on the basic theories in the Qur'an.

Table 1 will show the difference between Islamic banking and conventional banking.

Table 1

The Difference Between Islamic Banking and Conventional Banking

\begin{tabular}{|l|l|}
\hline Islamic banking & Conventional banking \\
\hline $\begin{array}{l}\text { In Islamic banking, money is not considered as a commodity. } \\
\text { However, it is considered as a medium of exchange and a way } \\
\text { to store value. } \\
\begin{array}{l}\text { Therefore, it will not be sold to the customer at a price higher } \\
\text { than the real value of the money (face value). }\end{array}\end{array}$ & $\begin{array}{l}\text { In Conventional, banking it is the opposite money is a } \\
\text { commodity and a medium of exchange. } \\
\text { In addition, it can be sold at a higher price than its real vale } \\
\text { face value) which leads to inflation. }\end{array}$ \\
\hline $\begin{array}{l}\text { After trading on goods or providing services, the profit that is } \\
\text { collected is the basis of earning profit in Islamic banks. }\end{array}$ & $\begin{array}{l}\text { The basis of charging an interest on the money or capital is the } \\
\text { time value. } \\
\text { That is how conventional banks earn profit. }\end{array}$ \\
\hline $\begin{array}{l}\text { The share of profit and loss is one of the Islamic banking } \\
\text { principles. }\end{array}$ & $\begin{array}{l}\text { If the customer or organization is suffering from a loss, the } \\
\text { charges are going to be charged on the customer no matter what. }\end{array}$ \\
\hline $\begin{array}{l}\text { Making agreements is necessary for exchanging of goods and } \\
\text { services. }\end{array}$ & $\begin{array}{l}\text { Agreements are not made in distributing of cash finance or } \\
\text { working capital finance, for exchanging goods and services. }\end{array}$ \\
\hline $\begin{array}{l}\text { Islamic banking tends to create link with the real sectors of the } \\
\text { economic system by using trade related activities. Since, the } \\
\text { money is linked with the real assets therefore it contributes } \\
\text { directly in the economic development. }\end{array}$ & $\begin{array}{l}\text { Conventional banking tends to be the third party in every deal, } \\
\text { which only lend money and charge interest, selling money for } \\
\text { money, without creating any link in the real sectors. }\end{array}$ \\
\hline
\end{tabular}

\section{What Principles Each Bank Follows?}

\section{Theoretical Basis for Islamic Banking}

Some people believe that Islamic banks are financial structure with interest-free system, but the truth is that Islamic banks are a complete system of justices both in economic and social fields.

One of the basic principles in Islamic banking is that the bank deals with the incentive system, the allocation of resources in the economy, the economic freedom and decision-making freedom, and the emphasis of the proper role of the government.

\section{Theoretical Basis for Conventional Banking}

Conventional banking is a system based on interest-bearing debt (Hossein, 2012). And income comes from commission, fees, and net interest (which they calculated by finding the difference from ending and the interest cost on deposit).

\section{United Arab Bank}

United Arabic Lender, G. T. S. D. (UAB) seemed to be involved in 1975 like a three way partnership concerning various UAE shareholders and the France international financial conglomerate, Société Générale (SG). 
Operating out of Sharjah and also functioning using 35 limbs through the UAE, the lending company delivers their consumers tailor-made financial solutions in equal management and business and also store financial, and it has mostly set up alone like a leading remedies supplier for any expanding business and also professional basic across the seven emirates. Throughout the provision of the complete range of management and business banking, retail banking, trade fund, SME financial and also Treasury solutions, UAB would be the traditional bank of preference among key management and business customers pieces within the UAE. With all the kick off involving their "Sadara" premium financial services and also Islamic Banking Services, the lending company has grown their store customer basic, and it is going to increase even more.

UAB possesses basically concluded a strategic connection with the Business Lender involving Qatar (CB). Referred to simple investment decision analysts from the place to be a natural strategic healthy, $\mathrm{CB}$ built a buy involving $40 \%$ involvement in UAB throughout 12,2007 , throughout one of the few GCC corner border agreements concerning two nationwide banking companies - the very first concerning banking companies from Qatar and the UAE.

United Arabic Lender is devoted to build eco-friendly long-term partners with his critical stakeholders, providing an outstanding consumer experience, generating shareholder value, in addition to following a cutting-edge consumer banking tactic whilst outstanding loyal to your country's history in addition to leading to the overall improvement in the UAE.

\section{Sharjah Islamic Bank}

Since 1975, SIB started servicing the society in 1975, providing banking services to individuals and companies. An Amiri decree, released by his highness Dr. Sheikh Sultan Bin Mohamed Al Qassimi, the member of the Supreme Council \& Ruler of Sharjah was issued to launch green-light for the bank's expedition. The bank was originally founded as National Bank of Sharjah and was suited the first bank to convert to Islamic banking in 2002.

Sharjah Islamic financial institution, the initial financial institution on the globe to efficiently transform via typical to Islamic. Sharjah Islamic financial institution is the most significant financial institution throughout Sharjah, functioning which has a committed manpower to serve each of the buyers.

\section{How Islamic Banks and Conventional Banks Faced the Financial Crisis (Results)?}

The recent experiences show that Islamic banks and their regulators coped well during the financial crisis in 2007-2008, but they were not immune to the negative effects of the subsequent recession (Habib, 2013).

Further, the conventional banks suffered and loosed a lot due to the huge crisis, they collapsed in other words. Even now, they still have the side effect due to the financial crisis.

US and European banks lost almost one trillion USD on assets and loans from 2007 to 2010, and many people lost their jobs, houses prices went to the lower price that it could be reached, and the list went on as a result due to 2007-2008 global crises

\section{What Are the Growth Percentages for Assets and Profitability, Between Islamic Banks and Conventional Banks? Before and After the Crisis, and Which Bank Got the Highest Percent of Growth on Assets and Profitability}

\section{United Arab Bank}

Table 2 presents the income statement and balance sheet of UAB during the period 2010-2014. 
Table 2

United Arab Bank Income Statement and Balance Sheet 2010-2014

\begin{tabular}{|c|c|c|c|c|c|c|c|c|c|}
\hline $\begin{array}{l}\text { Income statement } \\
\text { (UAB) }\end{array}$ & 2010 & Change & 2011 & Change & 2012 & Change & 2013 & Change & 2014 \\
\hline Interest income & 412,070 & $23.8 \%$ & 509,968 & $41.3 \%$ & 720,691 & $33.56 \%$ & 962,531 & $28.19 \%$ & $1,233,842$ \\
\hline Interest expenses & $(60,797)$ & $25.18 \%$ & $(76,108)$ & $846.9 \%$ & $(153,642)$ & $11.93 \%$ & $(171,972)$ & $30.52 \%$ & $(224,453)$ \\
\hline Net intrest income & 351,273 & $23.5 \%$ & 433,860 & $30.7 \%$ & 567,049 & $39.42 \%$ & 790,559 & $27.68 \%$ & $1,009,389$ \\
\hline $\begin{array}{l}\text { Net fees and } \\
\text { commission income }\end{array}$ & 70,131 & $10.9 \%$ & 77,742 & $3.7 \%$ & 80,597 & $36.82 \%$ & 110,272 & $9.80 \%$ & 121,074 \\
\hline $\begin{array}{l}\text { Net foreign } \\
\text { exchange income }\end{array}$ & 30,561 & $1.4 \%$ & 30,983 & $16.99 \%$ & 36,247 & $58.98 \%$ & 57,627 & $51.33 \%$ & 87,207 \\
\hline $\begin{array}{l}\text { Other operating } \\
\text { income }\end{array}$ & 42,750 & $-3.18 \%$ & 41,391 & $96 \%$ & 81,135 & $-0.12 \%$ & 81,037 & $91.90 \%$ & 155,510 \\
\hline $\begin{array}{l}\text { Total operating } \\
\text { income }\end{array}$ & 490,221 & $18.6 \%$ & 581,494 & $31.6 \%$ & 765,028 & $35.88 \%$ & $1,039,495$ & $32.10 \%$ & $1,373,180$ \\
\hline $\begin{array}{l}\text { Provision for credit } \\
\text { losses }\end{array}$ & $(19,298)$ & $265.5 \%$ & $(70,534)$ & $72.4 \%$ & $(121,605)$ & $38.53 \%$ & $(168,464)$ & $122.05 \%$ & $(374,075)$ \\
\hline $\begin{array}{l}\text { Net operating } \\
\text { income }\end{array}$ & 470,923 & $8.5 \%$ & 510,960 & $25.9 \%$ & 643,423 & $35.37 \%$ & 871,031 & $14.70 \%$ & 999,105 \\
\hline Personnel expenses & $(116,292)$ & $9.19 \%$ & $(126,977)$ & $13.9 \%$ & $(144,646)$ & $40.30 \%$ & $(202,937)$ & $24.21 \%$ & $(252,062)$ \\
\hline $\begin{array}{l}\text { Depreciation on } \\
\text { property and } \\
\text { equipment }\end{array}$ & $(9,076)$ & $22 \%$ & $(11,070)$ & $12.18 \%$ & $(12,418)$ & $28.01 \%$ & $(15,896)$ & $66.76 \%$ & $(26,508)$ \\
\hline $\begin{array}{l}\text { Other operating } \\
\text { expenses }\end{array}$ & $(37,554)$ & $13.9 \%$ & $(42,759)$ & $79 \%$ & $(76,541)$ & $30.28 \%$ & $(99,719)$ & $15.45 \%$ & $(115,127)$ \\
\hline $\begin{array}{l}\text { Total operating } \\
\text { expenses }\end{array}$ & $(162,922)$ & $11 \%$ & $(180,806)$ & $29.2 \%$ & $(233,605)$ & $36.36 \%$ & $(318,552)$ & $23.59 \%$ & $(393,697)$ \\
\hline Net income & 308,001 & $7.2 \%$ & 330,154 & $24.1 \%$ & 409,818 & $34.81 \%$ & 552,479 & $9.58 \%$ & 605,408 \\
\hline EPS & 0.31 & & 0.33 & & 0.40 & & 0.54 & & 0.52 \\
\hline $\begin{array}{l}\text { Balance sheet } \\
\text { (UAB) }\end{array}$ & 2010 & Change & 2011 & Change & 2012 & Change & 2013 & Change & 2014 \\
\hline $\begin{array}{l}\text { Cash and balances } \\
\text { with UAE Central } \\
\text { Bank }\end{array}$ & 383,856 & $42.9 \%$ & 548,594 & $106.4 \%$ & $1,132,160$ & $15.0 \%$ & $1,301,775$ & $39.08 \%$ & $1,810,558$ \\
\hline Due from banks & $1,206,855$ & $21.7 \%$ & $1,468,301$ & $-9.3 \%$ & $1,332,281$ & $38.7 \%$ & $1,848,253$ & $4.60 \%$ & $1,933,231$ \\
\hline Loans and advances & $5,497,482$ & $42.7 \%$ & $7,843,753$ & $38.7 \%$ & $10,881,493$ & $40.5 \%$ & $15,285,481$ & $17.37 \%$ & $17,940,903$ \\
\hline $\begin{array}{l}\text { Investments in debt } \\
\text { securities }\end{array}$ & 512,340 & $16.3 \%$ & 595,663 & $124.4 \%$ & $1,336,480$ & $20.9 \%$ & $1,615,417$ & $53.92 \%$ & $2,486,530$ \\
\hline Other investments & 34,226 & $521.01 \%$ & 212,548 & $-93.9 \%$ & 12,900 & $472.1 \%$ & 73,802 & $50.12 \%$ & 110,794 \\
\hline $\begin{array}{l}\text { Property and } \\
\text { equipment }\end{array}$ & 73,253 & $44.92 \%$ & 106,155 & $61.2 \%$ & 171,125 & $24.1 \%$ & 212,292 & $92.71 \%$ & 409,115 \\
\hline Other assets & 34,057 & $67.6 \%$ & 57,081 & $1213 \%$ & 749,428 & $61.8 \%$ & $1,212,736$ & $-16.04 \%$ & $1,018,154$ \\
\hline Total asset & $7,742,069$ & $39.9 \%$ & $10,832,095$ & $44.2 \%$ & $15,615,867$ & $38.0 \%$ & $21,549,756$ & $19.30 \%$ & $25,709,285$ \\
\hline Due to banks & 948,888 & $-8.26 \%$ & 870,523 & $103.5 \%$ & $1,771,872$ & $-38.1 \%$ & $1,097,174$ & $-22.81 \%$ & 846,914 \\
\hline Customers' deposits & $4,258,551$ & $72.4 \%$ & $7,343,110$ & $37.5 \%$ & $10,094,283$ & $48.9 \%$ & $15,034,837$ & $24.50 \%$ & $18,718,297$ \\
\hline $\begin{array}{l}\text { Islamic customers' } \\
\text { deposits }\end{array}$ & 591,615 & $-18.8 \%$ & 480,319 & $33.8 \%$ & 642,617 & $157.1 \%$ & $1,652,445$ & $22.22 \%$ & $2,019,655$ \\
\hline Other liabilities & 95,056 & $12.7 \%$ & 107,118 & $702 \%$ & 859,220 & $49.4 \%$ & $1,283,769$ & $-5.53 \%$ & $1,212,758$ \\
\hline Total liabilities & $5,894,110$ & $49.3 \%$ & $8,801,070$ & $51.9 \%$ & $13,367,992$ & $42.6 \%$ & $19,068,225$ & $19.56 \%$ & $22,797,624$ \\
\hline Share capital & 996,401 & $0.0 \%$ & 996,401 & $0.0 \%$ & 996,401 & $0.0 \%$ & 996,401 & $15.00 \%$ & $1,145,861$ \\
\hline Special reserve & 222,873 & $14.8 \%$ & 255,888 & $16 . \%$ & 296,870 & $18.6 \%$ & 352,118 & $17.19 \%$ & 412,659 \\
\hline Statutory reserve & 305,428 & $10.8 \%$ & 338,443 & $12.1 \%$ & 379,425 & $14.6 \%$ & 434,673 & $13.93 \%$ & 495,214 \\
\hline General reserve & 9,311 & $0.0 \%$ & 9,311 & $0.0 \%$ & 9,311 & $0.0 \%$ & 9,311 & $0.00 \%$ & 9,311 \\
\hline
\end{tabular}


Table 2 continued

\begin{tabular}{llllllllll}
\hline $\begin{array}{l}\text { Balance sheet } \\
\text { (UAB) }\end{array}$ & 2010 & Change & 2011 & Change & 2012 & Change & 2013 & Change & 2014 \\
\hline Revaluation reserve & 22,847 & $-5.1 \%$ & 21,671 & $-33 \%$ & 14,593 & $-76.6 \%$ & 3,409 & $-78.00 \%$ & 750 \\
Retained earnings & 322,092 & $31.76 \%$ & 424,368 & $28.5 \%$ & 545,155 & $35.3 \%$ & 737,494 & $24.04 \%$ & 914,759 \\
$\begin{array}{l}\text { Cumulative changes } \\
\text { in fair values }\end{array}$ & $(30,993)$ & $-51.4 \%$ & $(15,057)$ & $-59 \%$ & $(6,120)$ & $-947.6 \%$ & $(51,875)$ & $28.95 \%$ & $(66,893)$ \\
$\begin{array}{l}\text { Total equity } \\
\text { Total liabilities and } \\
\text { equity }\end{array}$ & $1,847,959$ & $9.9 \%$ & $2,031,025$ & $10.7 \%$ & $2,247,875$ & $10.4 \%$ & $2,481,531$ & $17.33 \%$ & $2,911,661$ \\
\hline
\end{tabular}

Source: United Arab Bank Annual Report financial statements 2010, 2011, 2012, 2013, 2014.

Table 3

Ratios Calculations of UAB During the Period 2010-2014

\begin{tabular}{|c|c|c|c|c|c|c|}
\hline UAB & Formula & 2010 & 2011 & 2012 & 2013 & 2014 \\
\hline ROA & $\frac{\text { Net Income }}{\text { Total Asset }}$ & $\begin{array}{l}308,001 / 7,742, \\
069 \\
=3.98 \%\end{array}$ & $\begin{array}{l}330,154 / \\
10,832,095 \\
=3.05 \%\end{array}$ & $\begin{array}{l}409,818 / \\
15,615,867 \\
=2.62 \%\end{array}$ & $\begin{array}{l}552,479 / \\
21,549,756 \\
=2.56 \%\end{array}$ & $\begin{array}{l}605,408 / \\
25,709,285 \\
=2.35 \%\end{array}$ \\
\hline ROE & $\frac{\text { NetIncome }}{\text { ToyalEquity }}$ & $\begin{array}{l}308,001 / \\
1,847,959 \\
=16.67 \% \\
\end{array}$ & $\begin{array}{l}330,154 / \\
2,031,025 \\
=16.26 \% \\
\end{array}$ & $\begin{array}{l}409,818 / \\
2,247,875 \\
=18.23 \%\end{array}$ & $\begin{array}{l}552,479 / \\
2,481,531 \\
=22.26 \%\end{array}$ & $\begin{array}{l}605,408 / \\
2,911,661 \\
=20.79 \%\end{array}$ \\
\hline $\begin{array}{l}\text { Net bank } \\
\text { operating } \\
\text { margin }\end{array}$ & $\begin{array}{l}\text { Total operating Revinew } \\
\frac{\text {-Total operating Expences }}{\text { TotalAsset }}\end{array}$ & $\begin{array}{l}(412,070+ \\
3,497+70,131 \\
+30,561+ \\
42,750)- \\
(60,797+7,991 \\
+162,992) / \\
7,742,069 \\
=4.23 \%\end{array}$ & $\begin{array}{l}(509,968+ \\
10,778+ \\
77,742+ \\
30,983+ \\
41,391)- \\
(76,108+ \\
13,260+ \\
180,806) / \\
10,832,095 \\
=3.70 \%\end{array}$ & $\begin{array}{l}(72,061+ \\
197,979)- \\
(153,642+ \\
233,605) / \\
15,615,867 \\
=3.40 \%\end{array}$ & $\begin{array}{l}(962,531+ \\
248,930)- \\
(171,972+ \\
318,552) / \\
21,549,756 \\
=3.35 \%\end{array}$ & $\begin{array}{l}(1,233,842+ \\
363,791)- \\
(224,453+ \\
39,3697) / \\
25,709,285 \\
=3.81 \%\end{array}$ \\
\hline $\begin{array}{l}\text { Net profit } \\
\text { margin }\end{array}$ & $\frac{\text { NetIncome }}{\text { Total operating Revinew }}$ & $\begin{array}{l}308,001 / \\
(412,070+ \\
3,497+70,131 \\
+30,561+ \\
42,750) \\
=55.10 \%\end{array}$ & $\begin{array}{l}330,154 / \\
(509,968+ \\
10,778+ \\
77,742+ \\
30,983+ \\
41,391) \\
=49.21 \%\end{array}$ & $\begin{array}{l}409,818 / \\
(72,061+ \\
197,979) \\
=44.61 \%\end{array}$ & $\begin{array}{l}552,479 / \\
(962,531+ \\
248,930) \\
=45.60 \%\end{array}$ & $\begin{array}{l}605,408 / \\
(1,233,842+ \\
363,791) \\
=37.89 \%\end{array}$ \\
\hline $\begin{array}{l}\text { Dividend pay } \\
\text { out ratio }\end{array}$ & $\frac{\text { Dividend }}{\text { Net Income }}$ & $\begin{array}{l}149,460 / \\
308,001 \\
=48.53 \% \\
\end{array}$ & $\begin{array}{l}159,424 / \\
330,154 \\
=48.29 \% \\
\end{array}$ & $\begin{array}{l}199,280 / \\
409,818 \\
=48.63 \% \\
\end{array}$ & $\begin{array}{l}249,100 / \\
552,479 \\
=45.09 \% \\
\end{array}$ & $\begin{array}{l}149,460 / \\
605,408 \\
=24.69 \% \\
\end{array}$ \\
\hline $\begin{array}{l}\text { Internal } \\
\text { growth rate }\end{array}$ & $\frac{(\mathrm{ROA} \times b)}{1-(\mathrm{ROA} \times b)}$ & $\begin{array}{l}0.0398 \times \\
0.5147 / \\
1-(0.0398 \times \\
0.5147) \\
=2.01 \%\end{array}$ & $\begin{array}{l}0.0305 \times \\
0.5171 / \\
1-(0.0305 \times \\
0.5171) \\
=1.60 \% \\
\end{array}$ & $\begin{array}{l}0.026 \times 0.52 / \\
1-(0.026 \times \\
0.52) \\
=1.37 \%\end{array}$ & $\begin{array}{l}0.025 \times 0.55 / \\
1-(0.025 \times \\
0.55) \\
=1.39 \%\end{array}$ & $\begin{array}{l}0.023 \times 0.75 / \\
1-(0.023 \times \\
0.75) \\
=1.76 \%\end{array}$ \\
\hline $\begin{array}{l}\text { Sustainable } \\
\text { growth rate }\end{array}$ & $\frac{(\mathrm{ROE} \times b)}{1-(\mathrm{ROE} \times b)}$ & $\begin{array}{l}0.1667 \times \\
0.5147 / \\
1-(0.1667 \times \\
0.5147) \\
=8.65 \%\end{array}$ & $\begin{array}{l}0.1626 \times \\
0.5171 / \\
1-(0.1626 \times \\
0.5171) \\
=9.18 \%\end{array}$ & $\begin{array}{l}0.182 \times 0.52 / \\
1-(0.182 \times \\
0.52) \\
=10.45 \%\end{array}$ & $\begin{array}{l}0.222 \times 0.55 / \\
1-(0.222 \times \\
0.55) \\
=13.91 \%\end{array}$ & $\begin{array}{l}0.207 \times 0.75 / \\
1-(0.207 \times \\
0.75) \\
=18.38 \%\end{array}$ \\
\hline
\end{tabular}

After the ratios of United Arab Bank have been calculated using Tabels 2 and 3 above, analyzis of them will be as follow. 


\section{Profitability}

The following indicators measure profitability:

- ROA (Return on Asset): which means how much the bank gain against each one AED.

- ROE (Return on Equity): which shows the amount the owners get against each one AED they invest in the bank.

According to Table 4, ROA decreased by $23.37 \%$, the profit increased by $7.2 \%$ unlike the asset growth with $39.9 \%$ and with profit margin that was weak in 2011 at $49.21 \%$.

In the next year 2012, ROA decreased to $2.26 \%$. The decreased amount was $14.1 \%$, with increased profit and asset $(24.1 \%, 44.2 \%)$, the ROA keeps decreasing with $2.29 \%$ in 2013 . Moreover, in 2014 also, a decrease in ROA from $2.56 \%$ in 2013 to $2.35 \%$ in the last year can be seen. With light increase in the profit $9.58 \%$, and increase in the asset with $19.3 \%$, these caused the ROA to decrease in the last five years. The increased total operating expenses over the past five years might helped the ROA to decrease. Moreover, the net profit margin also decreased except in 2013 it increased to reach $45.60 \%$ and decreased in the next year.

The increased operational expenses with $26.02 \%$ in 2014 , caused decrease in the net profit margin $37.89 \%$ in the last year, these two factors caused a decline in the ROA at that year.

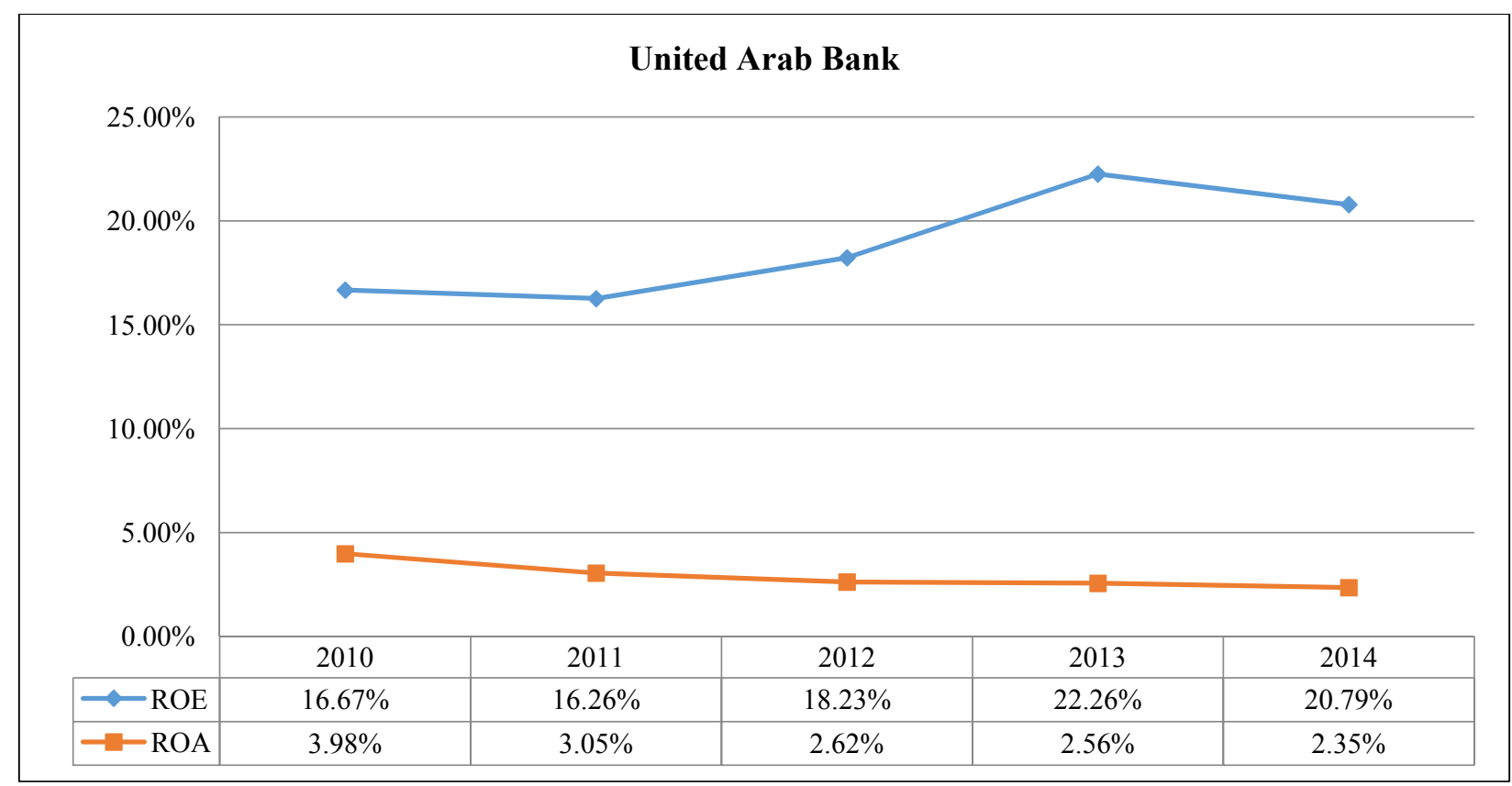

Figure 1. UAB ROE and ROA trend.

Table 4

Percentage Change of ROE and ROA of UAB 2010-2014

\begin{tabular}{llllll}
\hline Change in percentage & 2010 & 2011 & 2012 & 2013 & 2014 \\
\hline ROA & - & $-23.37 \%$ & $-14.1 \%$ & $-2.29 \%$ & $-8.2 \%$ \\
ROE & - & $-2.46 \%$ & $12.12 \%$ & $22.12 \%$ & $-6.60 \%$ \\
\hline
\end{tabular}

Figure 1 shows the trend of changes in both ROE and ROA during the period 2010-2014. As for the ROE, it keeps fluctuating between increasing and decreasing from 2010 to 2014. In the period from 2010 to 2011 , It showed a decrease with $2.46 \%$, with low increase in the profit $7.2 \%$ and increase in equity with $9.9 \%$, which 
caused a decrease in ROE at these two years. Nevertheless, in 2012, an increase with $12.12 \%$ can be seen, because of the increase in profit with $24.1 \%$ and light increase in the equity $10.7 \%$, which led to increased ROE at that year.

The same thing goes in 2013 with increase in the profit $34.81 \%$, and light increase in equity $10.4 \%$, that helped the ROE increase to achieve $22.12 \%$ in 2013.

However, in 2014 , the equity increased with $17.33 \%$, and with profit at $9.58 \%$; the ROE decreased by $6.60 \%$. The increase in the loans and advances with $17.37 \%$, and the provision for credit loses $122.05 \%$ in 2014 in the balance sheet might helped to decrease the ROE and also the net income.

\section{Sharjah Islamic Bank}

Table 5 presents the income statement and balance sheet of SIB during the period 2010-2014 while Table 6 shows main ratios calculations using the bank financial statements.

Table 5

Sharjah Islamic Bank Balance Sheet and Income Statement

\begin{tabular}{|c|c|c|c|c|c|c|c|c|c|}
\hline Balance sheet (SIB) & 2010 & Change & 2011 & Change & 2012 & Change & 2013 & Change & 2014 \\
\hline $\begin{array}{l}\text { Cash and balances } \\
\text { with banks and other }\end{array}$ & $1,921,694$ & $-7.87 \%$ & $1,770,432$ & $0.72 \%$ & $1,783,237$ & $26.78 \%$ & $2,260,757$ & $35.67 \%$ & $3,067,083$ \\
\hline $\begin{array}{l}\text { Wakalah and } \\
\text { murabaha } \\
\text { arrangements with } \\
\text { financial institutions }\end{array}$ & $2,242,617$ & $4.41 \%$ & $2,341,534$ & $1.32 \%$ & $2,372,410$ & $21.26 \%$ & $2,876,670$ & $11.76 \%$ & $3,214,863$ \\
\hline $\begin{array}{l}\text { Financing } \\
\text { receivables }\end{array}$ & $2,118,142$ & $11.92 \%$ & $2,370,688$ & $17.22 \%$ & $2,778,882$ & $42.55 \%$ & $3,961,401$ & $38.13 \%$ & $5,471,701$ \\
\hline Leased asset & $7,535,640$ & $6.92 \%$ & $8,056,746$ & $-1.07 \%$ & $7,970,489$ & $7.37 \%$ & $8,558,005$ & $5.12 \%$ & $9,002,953$ \\
\hline $\begin{array}{l}\text { Investment } \\
\text { securities }\end{array}$ & 471,664 & $55.73 \%$ & 734,536 & $16.63 \%$ & 856,681 & $45.17 \%$ & $1,243,649$ & $27.14 \%$ & $1,581,167$ \\
\hline $\begin{array}{l}\text { Investment } \\
\text { properties }\end{array}$ & 179,076 & $6.68 \%$ & 191,044 & $16.88 \%$ & 223,288 & $51.98 \%$ & 339,352 & $31.28 \%$ & 445,490 \\
\hline $\begin{array}{l}\text { Properties } \\
\text { held for sale }\end{array}$ & $1,016,675$ & $2.78 \%$ & $1,044,989$ & $3.64 \%$ & $1,083,034$ & $3.44 \%$ & $1,120,268$ & $27.69 \%$ & $1,430,465$ \\
\hline Other asset & 360,777 & $13.14 \%$ & 408,198 & $-3.38 \%$ & 394,381 & $17.14 \%$ & 461,992 & $84.32 \%$ & 851,542 \\
\hline $\begin{array}{l}\text { Property and } \\
\text { equipment }\end{array}$ & 820,876 & $-0.72 \%$ & 814,975 & $4.77 \%$ & 853,827 & $6.56 \%$ & 909,807 & $4.16 \%$ & 947,624 \\
\hline Total asset & $16,667,161$ & $6.40 \%$ & $17,733,142$ & $3.29 \%$ & $18,316,229$ & $18.65 \%$ & $21,731,901$ & $19.7 \%$ & $26,012,888$ \\
\hline Customers deposits & $10,378,134$ & $0.20 \%$ & $10,398,853$ & $9.00 \%$ & $11,334,541$ & $5.00 \%$ & $11,901,007$ & $22.61 \%$ & $14,591,968$ \\
\hline Due to banks & 677,089 & $33.07 \%$ & 900,972 & $-47.81 \%$ & 470,190 & $177.85 \%$ & $1,306,433$ & $87.97 \%$ & $2,455,664$ \\
\hline Sukuk payable & 825,831 & $77.16 \%$ & $1,463,062$ & $0.095 \%$ & $1,464,457$ & $125.06 \%$ & $3,295,889$ & $0.086 \%$ & $3,298,733$ \\
\hline Other liabilities & 300,578 & $37.65 \%$ & 413,742 & $26.50 \%$ & 523,377 & $12.49 \%$ & 588,730 & $62.46 \%$ & 956,453 \\
\hline Zakat payable & 136,720 & $9.97 \%$ & 150,355 & $-46.95 \%$ & 79,766 & $30.30 \%$ & 103,935 & $17.07 \%$ & 121,678 \\
\hline Total liabilities & $12,318,352$ & $8.19 \%$ & $13,326,984$ & $4.09 \%$ & $13,872,331$ & $23.96 \%$ & $17,195,994$ & $23.53 \%$ & $21,242,496$ \\
\hline Share capital & $2,425,500$ & $0.00 \%$ & $2,425,500$ & $0.00 \%$ & $2,425,500$ & $0.00 \%$ & $2,425,500$ & $0.00 \%$ & $2,425,500$ \\
\hline Legal reserve & $1,327,617$ & $0.00 \%$ & $1,327,617$ & $0.046 \%$ & $1,328,226$ & $0.15 \%$ & $1,330,233$ & $0.03 \%$ & $1,330,626$ \\
\hline Statutory reserve & 89,008 & $0.00 \%$ & 89008 & $0.00 \%$ & 89,008 & $0.00 \%$ & 89,008 & $0.00 \%$ & 89,008 \\
\hline Fair value reserve & $(15,426)$ & $32.77 \%$ & $(20,481)$ & $68.30 \%$ & $(34,470)$ & $23.86 \%$ & $(42,693)$ & $60.91 \%$ & $(68,698)$ \\
\hline Retained earnings & 522,110 & $11.95 \%$ & 584,514 & $8.76 \%$ & 635,634 & $15.45 \%$ & 733,859 & $10.64 \%$ & 811,956 \\
\hline $\begin{array}{l}\text { Total shareholders } \\
\text { equity }\end{array}$ & $4,348,809$ & $1.31 \%$ & $4,406,158$ & $0.86 \%$ & $4,443,898$ & $2.07 \%$ & $4,535,907$ & $1.16 \%$ & $4,588,392$ \\
\hline $\begin{array}{l}\text { Total liabilities and } \\
\text { shareholders equity }\end{array}$ & $16,667,161$ & $6.40 \%$ & $17,733,142$ & $3.29 \%$ & $18,316,229$ & $18.65 \%$ & $21,731,901$ & $19.70 \%$ & $26,012,888$ \\
\hline
\end{tabular}


Table 5 continued

\begin{tabular}{|c|c|c|c|c|c|c|c|c|c|}
\hline $\begin{array}{l}\text { Income statement } \\
\text { (SIB) }\end{array}$ & 2010 & change & 2011 & change & 2012 & change & 2013 & change & 2014 \\
\hline $\begin{array}{l}\text { Income from } \\
\text { murabaha and } \\
\text { leasing }\end{array}$ & 724,787 & $0.87 \%$ & 731,066 & $-4.90 \%$ & 695,234 & $-0.34 \%$ & 692,879 & $13.53 \%$ & 786,595 \\
\hline Profit on Sukuk & $(9,127)$ & $438.40 \%$ & $(49,112)$ & $43.99 \%$ & $(70,715)$ & $56.26 \%$ & $(110,496)$ & $14.40 \%$ & $(126,627)$ \\
\hline $\begin{array}{l}\text { Fees, commission } \\
\text { and other income }\end{array}$ & 164,524 & $-10.13 \%$ & 147,858 & $26.89 \%$ & 187,612 & $80.60 \%$ & 338,824 & $46.75 \%$ & 497,219 \\
\hline Total income & 880,184 & $-5.72 \%$ & 829,812 & $-2.13 \%$ & 812,131 & $13.43 \%$ & 921,207 & $25.62 \%$ & $1,157,187$ \\
\hline $\begin{array}{l}\text { General and } \\
\text { administrating } \\
\text { expenses }\end{array}$ & $(31,442)$ & $904.4 \%$ & $(315,808)$ & $6.58 \%$ & $(336,578)$ & $15.04 \%$ & $(387,205)$ & $10.48 \%$ & $(427,769)$ \\
\hline $\begin{array}{l}\text { Net operating } \\
\text { income }\end{array}$ & 579,543 & $-11.31 \%$ & 514,004 & $-7.48 \%$ & 475,553 & $12.29 \%$ & 534,002 & $36.59 \%$ & 729,418 \\
\hline $\begin{array}{l}\text { Provision-net of } \\
\text { recoveries }\end{array}$ & $(31,442)$ & $45.90 \%$ & $(45,873)$ & $-18.5 \%$ & $(37,391)$ & $171.78 \%$ & $(101,621)$ & $142.54 \%$ & $(246,469)$ \\
\hline $\begin{array}{l}\text { Net profit before } \\
\text { distribution to } \\
\text { depositors }\end{array}$ & 548,101 & $-14.59 \%$ & 468,131 & $-6.40 \%$ & 438,162 & $-1.32 \%$ & 432,381 & $11.7 \%$ & 482,949 \\
\hline $\begin{array}{l}\text { Distribution to } \\
\text { depositors }\end{array}$ & $(281,692)$ & $-22.96 \%$ & $(217,010)$ & $-23.4 \%$ & $(166,159)$ & $-24.58 \%$ & $(125,313)$ & $-15.59 \%$ & $(105,779)$ \\
\hline Net profit & 266,409 & $-5.74 \%$ & 251,121 & $8.32 \%$ & 272,003 & $12.89 \%$ & 307,068 & $22.83 \%$ & 377,176 \\
\hline Earning per share & 0.11 & & 0.10 & & 0.11 & & 0.13 & & 0.16 \\
\hline
\end{tabular}

Source: United Arab Bank Annual Report financial statements 2010, 2011, 2012, 2013, 2014.

Table 6

Ratios Calculations of SIB During the Period 2010-2014

\begin{tabular}{|c|c|c|c|c|c|c|}
\hline (SIB) & Formula & 2010 & 2011 & 2012 & 2013 & 2014 \\
\hline \multirow{3}{*}{ ROA } & Not Incomo & $266,409 /$ & $251,121 /$ & $272,003 /$ & $307,068 /$ & $377,176 /$ \\
\hline & Net Income & $16,667,161$ & $17,733,142$ & $18,316,229$ & $21,731,901$ & $26,012,888$ \\
\hline & Total Asset & $=1.59 \%$ & $=1.41 \%$ & $=1.48 \%$ & $=1.41 \%$ & $=1.44 \%$ \\
\hline \multirow{3}{*}{ ROE } & NetIncome & $266,409 /$ & $251,121 /$ & $272,003 /$ & $307,068 /$ & $377,176 /$ \\
\hline & 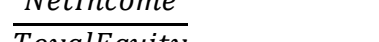 & $4,348,809$ & $4,406,158$ & $4,443,898$ & $4,535,907$ & $4,588,392$ \\
\hline & ToyalEquity & $=6.12 \%$ & $=5.6 \%$ & $=6.1 \%$ & $=6.7 \%$ & $=8.2 \%$ \\
\hline \multirow{7}{*}{$\begin{array}{l}\text { Net bank } \\
\text { Operating } \\
\text { Margin }\end{array}$} & & $(724,787+$ & $(731,066+$ & $(695,234,+$ & $(692,879+$ & $(786,595+$ \\
\hline & & $164,524)-$ & $147,858)-$ & $187,612)-$ & $338,824)-$ & $497,219)-$ \\
\hline & Total operating Revinew & $(9,127+$ & $(49,112+$ & $(70,715+$ & $(110,496+$ & $(126,627+$ \\
\hline & -Total operating Expences & $300,641+$ & $315,808+$ & $336,578+$ & $387,205+$ & $427,769+$ \\
\hline & TotalAsset & $281,692) /$ & $217,010) /$ & $166,159) /$ & $15,313) /$ & $105,773) /$ \\
\hline & & $16,667,161$ & $17,733,142$ & $18,316,229$ & $21,731,901$ & $26,012,888$ \\
\hline & & $=1.78 \%$ & $=1.67 \%$ & $=1.68 \%$ & $=1.88 \%$ & $=2.39 \%$ \\
\hline \multirow{3}{*}{$\begin{array}{l}\text { Net profit } \\
\text { margin }\end{array}$} & $n e$ & $266,409 /$ & $251,121 /$ & $272,003 /$ & $307,068 /$ & $377,176 /$ \\
\hline & T & 889,311 & 878,924 & 882,846 & $1,031,703$ & $1,283,814$ \\
\hline & Total operating Revinew & $=29.95 \%$ & $=28.57 \%$ & $=30.8 \%$ & $=29.76 \%$ & $=29.37 \%$ \\
\hline \multirow{3}{*}{$\begin{array}{l}\text { Dividend } \\
\text { payout } \\
\text { ratio }\end{array}$} & & $115,500 /$ & $133,402 /$ & $145,530 /$ & $145,530 /$ & $242,550 /$ \\
\hline & Dividend & 266,409 & 251,121 & 272,003 & 307,068 & 377,176 \\
\hline & Net Income & $=0.43 \%$ & $=0.53 \%$ & $=0.54 \%$ & $=0.47 \%$ & $=0.64 \%$ \\
\hline \multirow{4}{*}{$\begin{array}{l}\text { Internal } \\
\text { growth rate }\end{array}$} & & $0.0159 \times 0.57 /$ & $0.0141 \times 0.47 /$ & $0.0148 \times 0.46 /$ & $0.0141 \times 0.53 /$ & $0.0144 \times 0.36 /$ \\
\hline & $(\mathrm{ROA} \times b)$ & $1-(0.0159 \times$ & $1-(0.0141 \times$ & $1-(0.0148 \times$ & $1-(0.0141 \times$ & $1-(0.0144 \times$ \\
\hline & $\overline{1-(\mathrm{ROA} \times b)}$ & $0.57)$ & $0.47)$ & $0.46)$ & $0.53)$ & $0.36)$ \\
\hline & & $=0.9145 \%$ & $=0.6671 \%$ & $=0.6854 \%$ & $=0.7529 \%$ & $=0.5211 \%$ \\
\hline \multirow{2}{*}{$\begin{array}{l}\text { Sustainable } \\
\text { growth rate }\end{array}$} & & $0.0612 \times 0.57 /$ & $0.056 \times 0.47 /$ & $0.061 \times 0.46 /$ & $0.067 \times 0.53 /$ & $0.082 \times 0.36 /$ \\
\hline & $\frac{(\mathrm{ROE} \times b)}{1-(1)}$ & $\begin{array}{l}1-(\times 0.57) \\
=3614 \%\end{array}$ & $1-(\times 0.47)$ & $1-(\times 0.46)$ & $1-(\times 0.53)$ & $1-(\times 0.36)$ \\
\hline
\end{tabular}




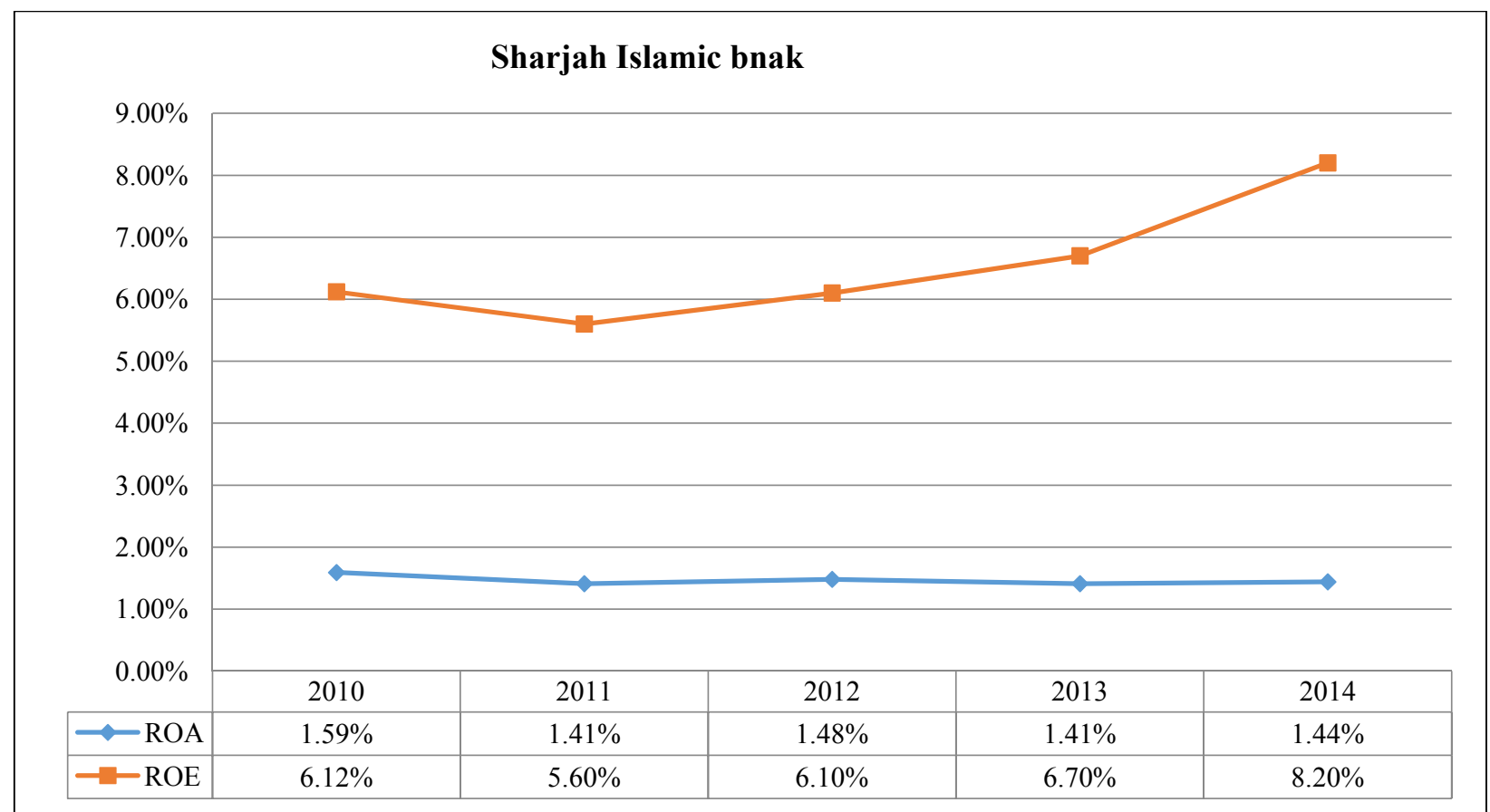

Figure 2. Ratios calculations of SIB during the period 2010-2014.

Table 7

Percentage Change of ROE and ROA of UAB 2010-2014

\begin{tabular}{llllll}
\hline Change in percentage & 2010 & 2011 & 2012 & 2013 & 2014 \\
\hline ROE & - & $-8.5 \%$ & $8.93 \%$ & $9.84 \%$ & $22.39 \%$ \\
ROA & - & $-11.32 \%$ & $4.96 \%$ & $-4.73 \%$ & $2.13 \%$ \\
\hline
\end{tabular}

It can be seen from Figure 2 and Table 7 that the ROE decreased by $8.5 \%$ in 2011 , and was $5.60 \%$. Because the profit decreased by $5.74 \%$, but the equity increased by $6.40 \%$ from 2010 to 2011 .

However, in 2012 the profit increased to $8.32 \%$ and the equity increased by $3.29 \%$. In 2013 , the equity increased to $18.63 \%$ but the profit increased with $12.89 \%$, which caused the increase in the ROE that year. However, in 2014, a light recover is noticeable by increase reached $19.7 \%$ in equity against the profit increased to $22.83 \%$. This big increase in the ROE might happen because the bank decided to increase the dividend payout ratio to $64 \%$. In addition, the increase in provision-net of recoveries with $142.54 \%$ in the last year might helped ROE to rise.

As for ROA, in 2010 the base year it started with 1.59\%. However, in the next year, the asset raised with $6.4 \%$, with a negative decrease in the profit (5.74\%) and light increase in the asset, the ROA increased to accomplish $1.41 \%$ in 2011 .

Nevertheless, the indicator improved in 2012 for increase in the asset and profit, respectively with $3.29 \%$ and $8.32 \%$, which led to increase in the ROA by $8.39 \%$.

From 2012 to 2013, the ROA decreased to $4.73 \%$, because the asset increased rapidly from $3.29 \%$ to $18.65 \%$. However, in the last year 2014, the asset increased to $19.7 \%$, but the profit raised with $22.83 \%$, which led to an increased ROA in the last year. The ROA fluctuated with the same rate, as the fluctuating net profit margin from 2010 to 2014 as the schedule above shows. 


\section{Which Bank Got the Highest Percent of Growth on Assets and Profitability?}

In the comparison between these two banks, each one of them achieved a growth at some point in the last five years, but the result found that the Islamic banks are more efficiency in its operations and less riskier, even though their growth is steady. However, the conventional banks are more fluctuating in one year they get a high growth rate but at the sane time have a decrease in the growth rates.

The study has compared the two main profitability factors ROA and ROE over the period of five years from 2010-2014 and entailed that the return on asset and equity is more stable in the Islamic bank but in the conventional bank the fluctuation is more, and that because growth in asset was not steady and the growth in equity wasn't in proportion of growth in asset, which leads to fluctuation in ROE. But in the Islamic bank, the growth in asset in proportion with growth in equity results to an increase in equity multiplier and eventually increases in ROE even if there was a decrease in ROA.

Therefore, over that period, the Islamic bank had 34\% growth on return on equity and $56 \%$ growth on asset while the conventional bank had only $24.7 \%$ growth in return on equity and $232 \%$ growth in asset. Which means that Islamic bank needed less growth in asset to increase its return by higher percentage than the conventional bank. Growth of Islamic bank asset was less than the quarter of growth in conventional bank asset but it gave a higher growth in return.

In the last two years, it has been found that the EPS are increasing in Sharjah Islamic Bank, but it decreased in United Arab Bank, even thought UAB Bank gives more EPS. However, it is much safer for the customers to invest in SIB Bank due to the financial stability and steady growth, more EPS means more profit, but more profit also means more risk. In addition, it has been noticed that both the ROA and ROE decreased in United Arab Bank, but increased in Sharjah Islamic Bank. However, the NPM decreased in 2014 in both banks but in SIB, the decrease was very light, unlike UAB that decreased from 45.60\% in 2013 to 37.895 in 2014.

It also proves that Islamic banks are more profitable, financially stable, and less risky. All that is because the Shari'ah principle the Islamic Banks follows unlike the conventional banks, which are more risky and less stable.

\section{What Are the Reasons for the Growth?}

Many reasons helped the banks that are studying to reach higher growth rate after the crisis:

- Lenders recover from the 2007-2008 worldwide credit card debt.

- The increase of government's spending on national infrastructure, rebounding within trade and tourism.

- Dubai's Expo 2020 wins helped the country's upgrade to emerging markets around the globe.

- Low interest levels incurred about financial loans.

- Stable returns, dividends in spite of an increasing capital base.

- The highest deposit-to-loan proportions.

- Stable entry to long-term funding and decreasing funding fees or costs.

All these reasons and more have helped to boost business confidence and activity.

\section{Will This Trend Continue in the Future?}

According to the result got from this research, the Islamic banks will continue with their stable expansion in the future with more loyal customers, profitability, and asset growth despite the fact that both banks face a good growth rate. 


\section{Conclusions}

This research studied the growth of Islamic banks and conventional banks, during five years after 2007-2008 financial crises from 2010 to 2014. The author introduced the study first by a comparison between Islamic and conventional banks in terms of the definition, basis, and principles that each bank follows.

Then this research did a case study by choosing one bank in the UAE under each type of banks. The researsh calculated and analyzed the basic ratios for measuring the growth as the ROA, ROE, net profit margin, net bank operating margin, sustainable growth, and internal growth rates. In addition, it compared the changes and growths in each year in the balance sheet and income statement. This author found that the Islamic banks are more stable and profitable but grow at steady rate. Also, it found that the conventional banks are more fluctuating in the growth rates in both ROA and ROE. They give more profit but more risky. And it gets effected very easily by any financial situation either positive or negative.

\section{References}

Habib, A. H. (2013). Islamic banking and financial crisis: Reputation, stability and risks. Edinburgh UP.

Hossein, A. (2012). Risk sharing in finance the islamic finance alternative. Singapore:John Wiley \& Sons.

Miniaoui, H., \& Gohou, G. (2013). Did Islamic banking perform better during the financial crisis? Evidence from the UAE. University of Wollongong in Dubai.

Mobeen Alam, H., Noreen, H., Karamat, M., \& Ilyas, M. (2011). Islamic Banking: Insulation Against US Credit Crisis, 2(10).

Muhammad Hanif. (2011). Differences and Similarities in Islamic and Conventional Banking, 2(2).

Zehri, C., Abdelbaki, A., \& Bouabdellah, N. (2012). Effects of the current financial crisis on Islamic banks compared to conventional banks. Banks and Bank Systems, 7(1). 